\title{
Dialogue in Critical Times
}

The term postmodernism and its cognates are used with numerous meanings and contexts (Jencks 1996). Here we will adopt a literal and historicist usage. The new is embraced by modernists - with enthusiasm, speed and energy. Later, in response, postmodernists bring a critical attitude, raising awkward questions, recognising ambiguity, using playfulness and irony. Although the current usage dates from the last century, it is hard to imagine a time, since conscious thought evolved, when a tension between modernists and postmodernists did not exist. So the answer given here to the question 'after postmodernism?' is 'more modernism and postmodernism', although the tension may not be thought of in the same way.

One nexus of tension between the modern and the postmodern is of supreme importance for our times. We are presented with the choice between an (attempted) continuation of the past trend of human domination on this planet and a turn to a different way, one that places human interests in a broad and long-term ecological context. In current discourse, the modern is generally associated with economic growth and technical efficiency (the latter to correct ecological excesses) - in short, with economics-as-usual (Cottey 2017). The postmodern is more associated with criticism of economics-as-usual. If, however, such a binary association is made simplistically, mutual incomprehension follows. There is a great need at present for an empathic dialogue (Hulme 2009) between economic traditionalists and those believing that a profound 'ecological turn' is needed.

Clearly, education plays a vital role here. At first sight the principal issue for educational theory (and also for practice) at the present time would appear to be - how does it relate to the growth vs ecology tension? In professional as well as public discourse about education, economistic arguments and counter-arguments are prominent. These are evidently related to the big issue but perhaps the relation is too prominent. Something deeper than the economistic is obscured, namely social power. Education is connected with power in ways that go beyond the more salient economistic issues. In particular, it is not widely noticed how coercive education is. Young people, from early years to early adulthood are subjected, directly and indirectly, to a degree of coercion significantly greater than that experienced by most other people. 
The root of 'education' is 'lead out' and a coercive, hierarchical education system depends strongly on leadership. There is no shortage of leaders but how many of them have the wisdom (Maxwell 2007) to lead the next generation to a good future? - a future that takes advantage of the benefits of modernism and, with the help of a postmodernist critical thoughtfulness, avoids the ills. Perhaps the problems of our present times, which have been recognised for nearly half a century and on which little progress has been made, call for less education and more learning together. Such a project requires continued dialogue between educational modernists and postmodernists.

\title{
References
}

Cottey, A. (2017). Environment change, economy change and reducing conflict at source.

Preprint (accepted for publication) available at

https://archive.uea.ac.uk/ c013/v2/preprints/envt-economy-conflict-v5-accepted.pdf

Hulme, M. (2009). Why we disagree about climate change. Cambridge, UK: Cambridge University Press.

Jencks, C. (1996). What is Post-Modernism? (4th ed.). Chichester, UK: Wiley.

Maxwell, N. (2007). From knowledge to wisdom: A revolution for science and the humanities. (2nd ed.). London: Pentire Press.

\author{
Alan Cottey \\ a.cottey@uea.ac.uk \\ University of East Anglia
}

$======$ END $=======$

[DCT-v2.docx Contribution submitted 23 October 2017 to editors of EPAT50 special issue] 